\title{
Representation of Bakassi Peninsula Conflict in Nigeria and Cameroon Print Media: A Critical Discourse Approach
}

\author{
Rotimi Taiwo (Ile-Ife) and Ebuka Igwebuike (Ota)
}

\begin{abstract}
The media discursive representation of participants and their roles in conflict situations is the focus of this study. The Nigeria-Cameroon clashes over the oil rich Bakassi Peninsula have been reported in newspapers from the two countries. In a bid to demonstrate how social attitudes are expressed in the discourse structure of news reports, the study analyzed news reports from four newspapers in the countries published in the heat of the armed conflicts between 2002 and 2010. The analysis focused on the thematic representations, the representation of actors in the material processes and power hierarchy. Our findings show that newspapers from each of the countries presented perspectives that seemed to favour their positive images before the entire world, each claiming victim status for their key actors. In terms of the different ideologies and values that motivate the news reports, the Nigerian newspapers adopted event-oriented reporting style, thereby appealing to the value of social justice. The news visibly portrayed the abuse of human rights and injustice by Cameroon security forces. On the other hand, Cameroon newspapers, while presenting misfortunes of the country's security forces in the hands of the militant groups from Nigeria, portrayed Cameroon security forces as responsive and capable of handling the conflict. The foregrounding of the virtues of the country's security forces in the news reports in Cameroon newspapers demonstrates that they are motivated by the ideology of patriotism.
\end{abstract}

\section{$1 \quad$ Introduction}

Conflicts in the Bakassi Peninsula, a 1,690-kilometer oil-rich border between Nigeria and Cameroon predates the post-independence period of the two nations. The disputes however began to draw increasing attention of local and international media since the International Court of Justice's judgment of 20.10.2002 that the Peninsula should be handed over to Cameroon. There have been several violent clashes between the Niger Delta militants and the Cameroon security forces represented by the gendarmes (the police) and the army. Nigerians living in Bakassi have often accused Cameroonian police of tax drive assaults, while the Nigerian government had to send in troops to protect its citizens from constant harassments by the Cameroon security agencies. The constant hostilities between the Cameroon security forces and groups of Bakassi civilians has resulted in widespread violence and hence attracted wide reportage in print and electronic media. The print media, especially Nigerian and Cameroon newspapers, have featured news on the conflicts almost on daily basis, especially 
in the heat of the crises. The key participants in the conflict are Cameroon security agents and Nigerians living in the Peninsula. Each of these groups has received divergent media coverage, especially in Nigerian and Cameroon print media. This study seeks to show through objective linguistic evidence how selected print media from the two countries project experiential issues through the way they characterize and represent the major participants and their roles in the conflict. The overall objective is to demonstrate how social attitudes are expressed in the discourse structure of print media news.

\section{Media Representation and Critical Discourse Analysis}

Language is essentially used to represent, make sense of and interpret the world around us. In recent time, the concept of "representation" has dominated a number of the critical discourse studies of media reports (Holquist 1983; Wenden 2005). Scholars in discourse and media studies have examined how people, places, objects, events and cultural identities are constructed in the process of production and reception. The central argument revolves around subjectivity or objectivity of the media in representing issues, events, people and actions. News reporting entails a representation of situation and events. However, it has been clearly asserted that news is not an ideologically neutral or straightforward process (Hall et al 1978; Fowler 1994; Taiwo 2007; Youssefi et al 2013) because news reporters and editors have to make decisions on "what to include and what to exclude" (Fairclough 1995: 4), what event or people gets reported in the news as well as how to represent what is chosen to be reported. In the views of Fowler (1991: 11), News is "the end product of a complex process which begins with a systematic sorting and selecting of events and topics according to a socially constructed set of categories". Thus, the media do not simply and transparently report events which are "naturally" newsworthy in themselves but all news embodies values and ideologies of the reporters. This is possible as language which is the main instrument of news is never free, innocent or neutral. News production is controlled by social actors, those van Dijk (2006a: 362) calls "the symbolic elites", that is professional journalists and writers "who have relative freedom and power to decide the discourse genre within their domain of power and determine the topics, style and presentation of discourse" (van Dijk 1989: 21).

The entire idea of representation in news is tied to power struggle, which is also the essence of politics (cf. Chilton/Schaffner 2002; Wenden 2005). Representation is the discursive assignment of meaning to groups, which is typically a competitive venture (Holquist 1983; Shapiro 1988). Therefore, according to Wenden (2005: 90), meaning is not embedded in the reality that is perceived but rather it is construed by linguistic representation. In critical discourse studies, ideology has been found to influence the manner in which groups represent matters of import and relevance to the body politic (cf. Fairclough 1995; Hodge/Kress 1993; van Dijk 2006b). Hence, the preoccupation of critical discourse analysis is to identify discursive representations and uncover the ideologies, values and biases in news as reflected in the construction of a particular representation of an event, group or action.

A number of existing critical discourse studies have focused on media representations of different groups, especially in conflict and war situations. For instance, representations of protesters and police in riots have sometimes focused on positive representation of the police as an agent of peace, especially during demonstrations, riots and protests, thus, supporting the general security ideology. Protesters have also been constructed as deviants, aggressive 
people, as well as the major source of violent events, while police, on the other hand, are mostly portrayed as victims of such acts (cf. Trew 1979; Fowler 1991; Lee/Craig 1992). However, in cases where the police engage in violence by manhandling or torturing people, their violent acts are mitigated and downplayed (cf. Fang 1994: 169). Media in reporting protests usually focus on the actions of the protesters instead of the cause of the protest (cf. McLeod/Hertog 1992: 260). In this case, the protesters or rioters are presented as deviants who confront the authorities or attack the police. A useful theoretical concept in analysing protest discourse is referred to as the "ideological square", which encapsulates the twin strategies of positive in-group description and negative out-group description. This portrays how in most instances, the police are represented as positive "us" and the victims of the attacks while the protesters are depicted negatively as negative "them" (cf. van Dijk 1998; Hakam 2009; Tong 2011). Prejudices may be expressed in news as positive self representation of a social group and negative "other" representation. According to van Dijk (1990: 170):

the social functions of such prejudiced communications are to share and normalize social knowledge and opinions with other in-group members, to exhibit and confirm in-group membership and allegiance or to exchange practical information that shows how to deal with them.

The representation of police in the British newspaper editorials about the 1985 disorders/riots was the focus of van Dijk (1991). Examining the editorials within the broad framework of racism in discourse, the study discovers that the riots are negatively evaluated as criminal actions of the Black community (especially the young Afro-Caribbean males) while the police are portrayed positively as the victims and responsive forces that deserve respect and support. The study supports the popular positive US and negative "other" representation.

Chiluwa (2011) is critical discourse study of how the media represented the role of Nigeria's Joint Military Task Force (JMTF) in the Niger Delta Crisis. The study examines how the media discursively present the activities of the military personnel deployed to protect oil installations and tackle insurgency and militancy in the region. Focusing on the dominant themes of violence and war as well as kidnappings and abductions, the study reveals that the Nigerian newspapers generally displayed positive representation of the Joint Military Task Force (JMTF) and negative representation of Niger Delta youth. Through exaggeration, labelling and agency attribution, the newspapers were sympathetic to the activities of the JMTF, identified as "Operation Restore Hope" and condemned the activities of the Niger Delta youth who were labelled "militants", "insurgents", and "hoodlums".

Taiwo (2011) demonstrates how the news reports in selected Western media were constructed to reflect certain forms of ideology towards Nigeria and by extension Africa. In a study of reports of some Western media on the Nigerian 2007 presidential election, the author shows how the organization of the elements in the clause structure through thematization, passivization, as well as the metaphorical projection of the nation, were used to project the image of Nigeria. The reports which also visibly foreground Africa x-rayed the continent through the Nigerian election and constructed a representation of the failure of Africa in the democratic experience.

Studies have generally shown that manipulation of grammatical forms and patterns in media discourse are obviously linked with media representations. A number of scholars have been 
able to demonstrate how representations are portrayed in news media discourse through the choices made in the language systems (cf. Sykes 1985; Yaghoobi 2009; Wattles/RadićBojanić 2007). Sykes (1985) observes how Black youths were presented as responsible for social problems. Thus, "Black youths stoned the police", where Black youths are placed as actors in an active construction which can be compared to a passive construction in which responsibility is de-emphasized; "The police were stoned by White youths" (Sykes 1985: 86). The implication of this is that the newspaper positioned the reader to view the Black youths as more to blame by presenting them as the primary agents who attacked the police.

In a comparative analysis of an Iranian newspaper and an American magazine's reportage of the Hizbulla-Isaeli War, Yaghoobi (2009) demonstrates how strategies such as passivisation and nominalisation enable the writers to manipulate the realizations of agency and power in the representation of action to produce particular meanings which are not always explicit for all readers.

From a different perspective, Chen (2008) carries out a critical discourse analysis of the SinoJapan conflict in The New York Times published from 01.01.2001 to 31.12.2006. The study compares the contrasting representations of Chinese and Japanese by the newspapers. According to the analysis of transitivity, the Chinese government, (especially its police officers) were portrayed as aggressive and violent by predominantly positioning them as agents of transactive processes of "dragging" and "wrestling", "knocking over" and "dragging away" some other participants. This also constructs the image of the police as instigators of violence. In contrast, the Japanese government and its people were depicted as more polite and rational, while their acts of violence were played down.

This study like existing ones reviewed earlier, adopts a critical discourse approach to newspaper reports of crises. While a good number of studies have been carried out from the political, legal, historical and sociolinguistic perspectives on the Bakassi Peninsula, a discursive construction and representation aspect of the crisis is yet to receive much scholarly attention. The focus of this study is on how the principal actors in the Bakassi Peninsula conflict are represented in selected print media emanating from two countries (Nigeria and Cameroon) at the centre of the conflict.

\section{$3 \quad$ Methodology}

The data for the study were purposively sampled from four (two from each country) widely read English-medium newspapers in Nigeria and Cameroon. The newspapers selected from Nigeria are The Guardian and Punch. The two newspapers are national newpapers published in Lagos. The Cameroonian newspapers are Cameroon Post, published in Beau, Eden, published in Limbe, both in the South-west province of Cameroon. These newspapers were published between August 2006 and August 2010, the period representing a significant period of conflict between the two countries.

Analysis of the data focused on how the organisation of the texts serves as a resource for making and exchanging meanings in texts. As a critical discourse analytic study, the study is concerned with the social functions that are represented in the organization of discourse. News writers adjust the grammar of a message to reflect their perception of a happening or a state of affairs - this Halliday $(1973,1985)$ refers to as the experiential meaning of language. 
Experiential meaning according to Eggins (1994) is expressed though the system of transitivity. Analysis of the news reports will be guided by Halliday's Systemic Functional Grammar with specific focus on the transitivity system. The verbal group is very important in the transitivity system because it is concerned with the relations between elements in a clause. The verb phrase determines the kind of object selected. This transitivity system allows an analysis of the meaning of clauses through the study of "choice of process types and participants roles seen as realizing interactants' encoding of their experimental reality: the world of action, relation, participants and circumstances that give context to their talk" (Eggins 1994: 220). Clauses in language represent events and processes of various kinds and transitivity aims to make clear and show these processes which they represent. The transitivity system distinguishes six kinds of processes and their specifically associated participants, each with its own grammatical relations. The Material Process is the process of doing or of happening with an Actor who is the doer and the Goal, which is affected by the action. Verbal Process is the process of saying, which includes the Sayer as the participant, Receiver is the one to whom the saying is directed and Verbiage is what is said. It could refer to the "content of what is said" which can be put directly (Quoted) or indirectly (Reported) or "the name of the saying" (Verbiage) (Halliday 1985: 141). These three can be differentiated in the following examples:

The secretary [SAYER] said [VERBAL PROCESS] I am tired [QUOTED] (content of what is said)

The secretary [SAYER] said [VERBAL PROCESS] she was tired [REPORTED].

I [SAYER] asked [VERBAL PROCESS] a simple question [VERBIAGE] (the name of the saying)

Mental Processes are processes of feeling, thinking and perceiving with the Senser, the conscious being (i. e. human or humanized) that is feeling, thinking or perceiving and the Phenomenon - which can be any material or abstract entity or even a fact which is "sensed" felt, thought or perceived. Relational Processes are processes of being. Any clause with a Relational Process may be used either to identify something with something else (identifying type) or to say that something is an attribute of something else (attributive type). Behavioral Processes are processes of physiological and psychological behaviour, like breathing, dreaming, smiling, coughing with one participant - the Behaver, who must be a conscious being. Existential Processes are processes that show that something exists (in the case of entities) or happens (in the case of events), with the nominal group, Existent as the only participant.

For the purpose of analysis in this study, our focus will be on three major representation issues: writer's choices that indicate representations of the conditions, events, practices, individuals, and groups that are the focus in the reports - thematic representations (Wenden 2005); the representations of the actors and their actions in the material process and the representations of the participants' power hierarchy. Thematic representations identifies the key themes that recur throughout the reports, representing individuals and groups, events, conditions and practices focused in the text. Representation of actor and actions will reveal how the experiential reality of the text is linguistically encoded, especially in the world of participants' actions. Participants' power hierarchy will present a general sense of grammatical 
construction of power hierarchy in the reports. It will present how participants are grammatically construed as powerful, less powerful or even powerless in the discourse. This is strongly linked with the reporting style and it has to do with the roles participants in the stories are made to take, which may be active or passive.

\section{Thematic Representations in the Reports}

Words or expressions through which a text or talk characterizes persons, groups, social relations, events or conditions that shape a conflict are chosen from among a wide range of options to reinforce and legitimize the ideology communicated through the discourse themes (cf. Wenden 2005: 94). Thematic representations in the reports are based on a general overview of the writers' choices, which reflect what they consider as relevant to the understanding of the topic. These representations of the entire events are reflected on the choice of expressions that paint the picture of the entire event from the point of view of the writer. Words chosen include: attacks, harassments, invasions, displacements, terrorism and killings. Since headlines as source of knowledge are naturally predisposed to present a specific version of truth, reality, or world order (cf. MacRitche/Seedat 2008: 339), this picture of thematic representations of the events is clearly portrayed in the headlines of the news as seen below.

R1: Bakassi returnees allege harassment, torture (Punch, Thursday, 29.10.2009)

R2: Camerounian gendarmes invade Bakassi Peninsula (Punch, Saturday, 12.08.2006)

R3: 23 Nigerians killed in Bakassi, 3,300 displaced (The Guardian, 18.12.2009)

R4: Cameroon troops killed in Bakassi - (The Post, Monday, 20.10.2008)

R5: Pirates attack Bamusso Gendarmerie Brigade - (Eden, Monday, April 05.04.2010)

R6: Bakassi boils again: 21 Cameroon soldiers killed - (Eden, 16.11.2007)

From the reports in the newspapers, the general picture of the episode is that of a struggle between the Cameroon security forces and the Nigerians living in Bakassi. In addition to the physical struggle between the security agents and these people, the media became the social space for contesting power between the two countries as we will later see in the analysis. The construction of "who did what and to whom" in the struggle is done through a deliberate choice of information to present a narrow or one-sided view in news emanating from each country. In the Nigerian newspapers, Nigerian residents in Bakassi were portrayed as the victims of "harassment", "torture", "invasion" and "killing", they were also described as "displaced persons" (see R1-R3). However, in the Cameroon newspapers, Cameroon soldiers were seen as the victims, as they were the ones "attacked" and "killed" (R4-R6). It is clear from these representations that the media from each country present perspectives that seemed to favour their images before the entire world, each claiming that the key actors were victims in the crises. This shows clearly the power of news agencies to censor or filter information in order to preserve or abolish the hegemony of social groups. 
Ebuka Igwebuike and Rotimi Taiwo: Representation of Bakassi Peninsula Conflict in Nigeria 133 and Cameroon Print Media

\section{$5 \quad$ Representation of Actor and Actions}

While the major actors in the reports were the Cameroon security agents, the Nigerians in Bakassi, the Nigerian military, the first two groups were clearly prominent in the news reports. For instance, the Nigerian military appeared as actors in just two of the reports, while Cameroon security agents and Nigerians in Bakassi took up the roles of Actors and Sayers in the reports. Most of the news revolved mainly around these actors, who were in the struggle for power control in the peninsula. The minority section of Nigerians in Bakassi who organized themselves into a militant group to combat the Cameroon security agents and defend the majority of Nigerian citizens in the peninsula became very prominent in the news. In spite of the presence of the Nigerian military in the Peninsula, they were hardly mentioned in the news. When they were mentioned at all, they were involved in the verbal process as Sayers, reporting the activities of the Cameroon security forces, as can be seen in the clauses below.

R7: The leader of the Nigerian Joint Task Force Major-Gen. Steve Guan [SAYER] confirmed [VERBAL PROCESS] at a news conference in Calabar that his team was aware of the Gendarmes activities and had made appropriate reports to the authorities [REPORTED] (Punch, Saturday, 12.08.2006)

R8: The Nigerian Army [SAYER] also said [VERBAL PROCESS] that the raid could have been carried out by the same group of gunmen that had earlier attacked a nearby oil terminal run by Exxon Mobil [REPORTED]. (The Guardian, Wednesday, 14.11.2007)

The Nigerian newspapers represent the Cameroon security forces deployed to the peninsula to keep peace as "killers" rather than protectors of the people. R9 below illustrates this. (Please note that the bold font in all the extracts is deliberately included by the authors to highlight words being emphasized. They were not emboldened originally in the reports).

R9: The people alleged that three weeks ago, six Nigerians, who went beyond the Nigerian territory into Cameroonian side to retrieve their logs from the forest in Archibong town area, were attacked by the gendarmes and four of them were killed, while two managed to escape. In yet another incident, the Ikang people at the beach averred that two Nigerians who were searching for oyster and periwinkles, were also attacked and killed for no just cause, as up till now, they have not come back home. It brings to six, the number of Nigerians allegedly killed by the Cameroonian gendarmes barely two months after handover. (The Guardian, 7.11.2009)

In R9, Cameroon police were represented as killers who engaged in violent "attacks and killings" - the repetition of verbs depicting these actions supports this view. Through the process of passivisation, The Guardian foregrounds Nigerians as the victims of the violent acts of the police. The extracts below from R9 show some passivized clauses with the participants and processes.

R9.1 Six Nigerians ... [GOAL] were attacked [MATERIAL PROCESS] by the Gendarmes [ACTOR] 
R9.2 ... four of them [GOAL] were killed [MATERIAL PROCESS]

R9.3 ...two [GOAL] were also attacked [MATERIAL PROCESS]

R9.4 ...killed [MATERIAL PROCESS] for no just cause [CIRCUMSTANCE]

R9.5 ... Nigerians [GOAL] allegedly killed MATERIAL PROCESS] by the Cameroonian gendarmes [ACTOR] barely two months after handover [CIRCUMSTANCE]

Note: The Actor in R9.2-4 (the gendermes), though omitted here, can be recovered from the text in an earlier clause.

In R9.1-R9.5 above, the Cameroon gendarmes were made to assume the participant role of Actor in the material processes, while the Nigerians in Bakassi became the Goal, the participant to whom the unfolding process extends. Cameroon gendarmes whose duty is to maintain law and order in the area are portrayed as the Agents of the material processes of doing, hence the attackers and killers of supposedly innocent Nigerians. The circumstances "for no just cause" and "barely two months after handover", further confirm the claims that the attacks and killings were unprovoked, therefore unjust. The action portrayed here is in opposition to the tenets of the Green Tree agreement and ICJ judgment which permits Nigerians to live freely and transact businesses in the area after the handover. The linguistic choices create a frame that draws readers' attention to selected information as can be seen in R10 and R11.

R10: But the experiences of all the victims put together could not measure up to the alleged humiliation suffered by Mrs. Atim Okon, 35. The gendarmes reportedly made her a widow when she was eight-month pregnant. She only saw her husband last on one fateful day when he left home for fishing business. He was believed to have been shot and thrown into the river by the gendarmes (Punch, 1.12.2008)

R11: One of the returnees, who identified herself as Irene Okon, said they had to leave Bakassi as a result of the hostile attitude of Camerounian gendarmes. Okon also claimed that some of the gendarmes shot sporadically at the disputed area to scare Nigerians away, adding that the development made them to move to Ibaka for safety. She expressed dissatisfaction at the way Nigerians were treated by the Camerounians and called on the Federal Government to come to their rescue. She said, "We are all Africans and even if the land has been ceded to them (Camerounians), it is not right for them to be hostile to us. I have stayed in Bakassi for 11 years and have lost almost all I worked for as a trader." (Punch, Monday, 11.08.2008)

In the extracts above, a woman was reportedly "made a widow" and one of the "returnees", who is also a victim as well as a witness, was made to report the "hostile attitude" of the Cameroon gendarmes to Nigerians. These episodic frames of the conflict in the form of narratives as well as event oriented reports of the experiences of those affected by the actions of the gendarmes was used in the news to appeal to the basic psychological impulses of the readers of the news. These particular individual stories were used to illustrate the broader issues identified in the news. Below are the participants and processes in the clauses. 
Ebuka Igwebuike and Rotimi Taiwo: Representation of Bakassi Peninsula Conflict in Nigeria 135 and Cameroon Print Media

R10.1: The gendarmes [ACTOR] made [MATERIAL PROCESS] her a widow [GOAL]

R10.2: He [AFFECTED] was believed [MENTAL PROCESS] to have been shot [PHENOMENON]

R10.3: ... and thrown [MATERIAL PROCESS] into the river [GOAL] by the gendarmes [ACTOR]

R11.1: One of the returnees, who identified herself as Irene Okon [SAYER], said [VERBAL PROCESS] they had to leave Bakassi as a result of the hostile attitude of Camerounian gendarmes [REPORTED]

R11.2: She [SAYER] said, [VERBAL PROCESS] "We are all Africans and even if the land has been ceded to them (Camerounians), it is not right for them to be hostile to us. I have stayed in Bakassi for 11 years and have lost almost all I worked for as a trader." [REPORTED]

The choices made in R10 portrays the fisherman as the victim - "affected" by the action of the gendarmes - having been "shot" and "thrown" into the river and the wife "made a widow". The acts of the gendarmes depict callousness. The Punch in R10 and R11 projects a vivid description of torture and a mental perception of the event. The speech reported in R11 presents the plight of a Nigerian who believed she had a stake in Bakassi having lived there for eleven years. The report gave her the opportunity to express the feelings and experience of Nigerians living in Bakassi.

The Nigerian newspaper reports also present the Cameroon police as bullies. The police are seen as turning their legitimate power into an instrument of intimidation and threats. R13 below throws light to this:

R13: He said a gendarmes patrol team had accosted him at sea and demanded N10,000 which he did not have, following which the officer tore his fishing nets, removed his 40HP engine, sank his boat and later beat him and abandoned him thinking he was dead (The Guardian, 01.12.2009)

R13 presents the complaint of one Nigerian who has undergone intimidation in the hands of the gendarmes. The Guardian reports it here in the form of a narration to present the police as intimidators and aggressors. A quick analysis of the transitivity process shows the different verbs that are employed in the material process to portray the violent actions of the police. The extracts below depict this:

R13.1: A gendarmes patrol team [ACTOR] had accosted [MATERIAL PROCESS] him [GOAL] at the sea [CIRCUMSTANCE]

R13.2. The officer [ACTOR] demanded [MATERIAL PROCESS] N1000 [GOAL]

R13.3. The officer [ACTOR] tore [MATERIAL PROCESS] his fishing net [GOAL]

R13.4. ...removed [MATERIAL PROCESS] his 40HP engine [GOAL]

R13.5. ...sank [MATERIAL PROCESS] his boat [GOAL]

R13.6. ... beat [MATERIAL PROCESS] him [GOAL]

R13.7. ... abandoned [MATERIAL PROCESS] him [GOAL] 
Cameroon soldiers are also portrayed as extortionists and brutes. The Nigerian media in this report gives details of all the illicit actions of the Cameroon security force. This could however be a deliberate account to show the world the untold suffering the Nigerian citizens experience in a region, which was once theirs and also to portray them as victims of the circumstance after the handover. The verbs in the material processes "accosted", "demanded", "tore", "removed", "sank", "beat", and "abandoned" illustrate violence. The processes portray the different kinds of suffering that the returnees have been subjected to in a bid to frustrate them out of the peninsula.

Aggression is another characteristic feature that the Cameroon police are associated with. Here the Nigerian newspaper reports depict the police as aggressors who invaded and terrorize the residents of the area.

R14: Most of the refugees fled without picking anything, as the Camerounian gendarmes stampeded them out with gunshots and horse whips (The Guardian, 14.06.2008)

R15: "We are in danger" - Bakassi natives cry out ... as Camerounian gendarmes terrorise them. There is palpable fear among Nigerians currently living in some parts of the southern Bakassi, following the terrorist acts of the gendarmes from Cameroon, who invaded the place since Thursday. (Punch, 13.08.2006)

R16: In fact, the entire camp reverberated with how the gendarmes brutalized, raped, destroyed and seized the property of Nigerians living in the peninsula (Punch, 10.01.2010)

In R14, the Cameroon gendarmes are represented as a riotous police who forcefully ejected Nigerians from the peninsula, hence, the description of Nigerians as "refugees", who have to flee from persecution. The verb phrase "fled without picking anything" captures their unprepared exit from the peninsula as they were frightened, attacked and evicted with military weapons. Terrorist acts of the gendarmes are captured in the texts through the verbs used to depict their actions, such as: "terrorise", "invade", "brutalise", "rape", "destroy", and "seize".

During the period towards the handover, Cameroon gendarmes were reported to have been ejecting the inhabitants of Bakassi in order for Cameroon to occupy the area. The view here is that the soldiers were obsessed with the eagerness to occupy the peninsula after it was ceded to Cameroon by the International Court of Justice. This so-called desperation on the part of the Cameroon gendarmes resulted into the series of violent acts committed by them, which run contrary to the stipulations of the Green Tree Accord and the International Court of Judgment that Nigerians in Bakassi are free to stay in the area after the handover.

In the Cameroon newspapers, the Cameroon security forces are represented in three major ways: as the victims of Nigerian militants in the peninsula border conflict, as the saviour of their people, and as a responsive and patriotic force defending the territorial integrity of their nation. This is clearly in contrast to the representations in Nigerian newspapers. The Cameroon newspapers claim victim-status for these security agents by focusing on the ills and misfortunes that befell the Cameroon security forces in the course of doing their legitimate security duties. As targets, the police are said to be victims of different actions, such as "abduction/kidnapping", "massacre", "raids", "assault", "assassination/killing", "murder" etc. 
Ebuka Igwebuike and Rotimi Taiwo: Representation of Bakassi Peninsula Conflict in Nigeria 137 and Cameroon Print Media

These acts are said to be perpetrated by Niger Delta militant groups and not even the Nigerian security forces, as can be seen in the extracts below.

R17: The Post learnt that five assailants, said to be Niger Delta rebels, in two speed boats, opened fire on Cameroonian soldiers at a fishing port called Jabane by 11 am, Saturday, October 18. According to a military source in Bakassi, some five assailants in two speed boats attacked a fishing boat on the Cameroonian territorial waters in a boundary area between Cameroon and Bakassi before Cameroonian soldiers pushed back the rebels shooting three out of the five assailants.... According to a communiqué signed by Cameroon's Minister of Defense, Remy Ze Meka, the assailants who were on board two speed boats attacked and wounded some of the Cameroonian soldiers. The communiqué states that the Cameroonian soldiers reacted by pursuing the assailants who fled towards Nigeria. (The Post, 20.10.2008)

R18: Unidentified gunmen considered to be pirates have attacked the Bamusso Gendarmerie Brigade in the Bakassi area. The assault on the security office was carried out last Sunday 28 March 2010. The pirates are said to have carted away at least 20 guns belonging to the brigade. Eden also gathered that the hoodlums equally took away two speedboats belonging to the Divisional Officer, DO, of Bamusso and the Gendarmerie Brigade.... It should be noted that this is the umpteenth time pirates are wreaking havoc in the Bakassi area. Shortly before the official handover of the peninsula by Nigeria to Cameroon, pirates launched an attack that led to the death of the Divisional Officer of Kombo Abedimo, Felix Morfaw and 21 Cameroonian soldiers. After that the pirates carried out other attacks and sometimes took hostages from oil installations. (Eden, 05.04.2010)

In R17 and R18, Cameroon security agents are presented as the victims and targets of the attacks in the peninsula. The verbs in the material processes: opened fire, attacked, wounded, carted away, and so on, describe the violent actions of Bakassi militant groups (Niger Delta militants) on the security agents. Below are the representations of the participant roles, the processes and the circumstantial roles in the clauses in Texts 9 and 10.

R17.1: Niger Delta rebels, in two speed boats [ACTOR] opened fire on [MATERIAL PROCESS] Cameroonian soldiers [GOAL] at a fishing port called Jabane by 11 am, Saturday, October 18 [CIRCUMSTANCE]

R17.2: ... some five assailants in two speed boats [ACTOR] attacked [MATERIAL PROCESS] a fishing boat [GOAL] on the Cameroonian territorial waters in a boundary area between Cameroon and Bakassi [CIRCUMSTANCE].

R17.3: ... the assailants who were on board two speed boats [ACTOR] attacked and wounded [MATERIAL PROCESS] some of the Cameroonian soldiers [GOAL].

R18.1: Unidentified gunmen considered to be pirates [ACTOR] have attacked [MATERIAL PROCESS] the Bamusso Gendarmerie Brigade in the Bakassi area [GOAL]. 
R18.2: the hoodlums [ACTOR] equally took away [MATERIAL PROCESS] two speedboats belonging to the Divisional Officer, DO, of Bamusso and the Gendarmerie Brigade [GOAL]

The reports present the Cameroon security forces as the target and focus of surprise attack/ambush by the Niger Delta militants, as they (Cameroon security forces) engage in their supposedly legal security duties of maintaining public order and preventing crimes in the area. In the text, the only responsibility of the soldiers is that they responded or "reacted by pursuing", the assailants towards Nigeria's end. This invariably portrays them as responsive and resistant actors. It also supports the "push back" syndrome which makes the police to be represented as only reacting in self defence and prevention of further crimes.

Two groups of people are identified in R17 and R18: the attackers described by various names - gunmen, assailants, rebels, pirates and hoodlums; and the victims (Cameroon soldiers). The attackers are portrayed with negative labels depicting violence, corresponding with their actions of "wreaking havoc", "launching attack", "taking hostages" etc. The words "pirates" and "hoodlums" share the semantic properties of being violent and lawless. Thus, in the text, the verb phrases "carted away at least 20 guns" and "took away two speedboats" respectively represent the activities that would typically associated with pirates and hoodlums. The receivers of the violent acts are the Cameroonian soldiers who lost their weapons of protection, boats, and some, ultimately their lives.

R19: The rebels have also called on all foreign oil exploiting and exploring companies who have not consulted with the "competent authorities" (meaning the rebels) to quit. The declarations came in the wake of a sustained bloody drama that began in November 2007 when 21 Cameroonian soldiers were mowed down by rebel fire, the June 10 killing of five military officials and a Divisional Officer. In yet another attack, three Cameroonian soldiers were wounded and the others routed. (The Post, 08.08.2008)

Also in the text, a succession of attacks between the rebels and established authorities is described as "bloody drama", which is a metaphorical representation of the series of deadly confrontations by the rebels.

Cameroon newspapers also represent the country's security forces as saviour of the people. They are portrayed as rescuers who free endangered Cameroonians and other nationals from their captors. R20 below captures this:

R20: Seven Chinese fishermen were seized off the coast of the peninsula by an armed group who held them for five days before Cameroon forces were able to free them on March, 17 (The Post, Monday, 29.05.2010)

R21: Contrary to some media reports, the Cameroon Army has taken a bold step to permanently stamp out insurgency in the Bakassi Peninsula in the wake of incessant attacks by yet to be identified assailants ahead of the 14 August final handover. (Eden, 28.07.2008)

In R20, the police are depicted saviours who were able to set free the abducted Chinese fishermen from their armed captors. As a professional and intelligent force, the police have succeeded in liberating the captives as well as imprisoning crime perpetrators. Part of the 
Ebuka Igwebuike and Rotimi Taiwo: Representation of Bakassi Peninsula Conflict in Nigeria 139 and Cameroon Print Media

saving strategies of the police include "fishing out the culprits of Monday's attacks" (The Post, 12.06.2008), "crushing the marauding rebels and bringing honour to the country" (The Post, 27.04.2009) and "clipping the wings of the sea pirates reigning terrors in the area" (Eden, 18.02.2009).

The verb phrases: fish out the culprits, crush the marauding rebels, bring honour to the country, and clip the wings of the sea pirates are carefully chosen to portray the professional and patriotic zeal with which the Cameroon security forces carry out their duties. The security agents have to "seek" and "pull out" (fishing out), "violently subdue" (crush) and "restrain" and "limit" (clipping the wings) the rebels.

In R21 Eden projects the conscious effort of the Cameroon army to restore law and order in the troubled region ahead of the handover. Insurgency as a violent act will ordinarily threaten peace, hence the need to stamp it out (to end it unpleasant by taking strong and determine action). The Cameroon security forces are therefore represented as being determined to end violence and save the area and the entire region from the impending threat of insurgency. The newspaper therefore projects the view that Cameroon (especially its soldiers) wants a peaceful handover on 14 August and thus, is eager to permanently end the violence that threatens the peaceful handover.

The Cameroon newspapers also represent the Security forces as defensive and responsive to attacks. For instance,

R22: According to a military source in Bakassi, some five assailants in two speed boats attacked a fishing boat on the Cameroon territorial waters in a boundary area between Cameroon and Bakassi before Cameroon soldiers pushed back the rebels shooting three out of the five assailants (The Post, 20.10.2008).

In the text, Cameroon soldiers' retaliation to attacks from the rebels is described as "pushing back" the rebels. Through the choice of "push back", the soldiers are exonerated from the blames of possible killing of three rebels, as this action is seen as resistance in self defence and a responsive mechanism. That is, the soldiers promptly defended attacks from the rebel and are able to thwart their incursion. The Post implicitly commends the heroic deeds of the soldiers and also brings to light the capability of the Cameroon soldiers to defeat and end impending attacks. Acts of heroism trail the prompt response of the soldiers in R23.

R23: The release stated that Cameroon military forces stationed in Jabane, informed of the attacks, went on a manhunt for the assailants and succeeded to sink one of their boats while the other is reported to have escaped towards the Nigerian end of the Peninsula. This time around there was no material or human casualties on the Cameroonian side. (Eden, 10.12.2008)

R24: It should be recalled that in riposte to the several attacks by the Nigerian pirates and continuous menaces, the Cameroonian army on Thursday 24 July went all out for action, killing about ten of the pirates, seizing their ammunitions and held others in captivity. (Eden, 28.07.2008)

R25: They were captured after reinforced Cameroon military forces in the Bakassi zone beat back an early morning incursion at their position by the Nigerian Niger Delta rebels (The Post, 28.07.2008). 
Eden in R23 commends the swift response of the soldiers that saw the end of a supposed attack by the "assailants". The verb phrase "...went on manhunt" and the verb "succeeded" not only help to echo the fact that the soldiers are capable of restoring sanity to the turbulent region, but as warning to the supposed troublemakers of that region. This creates an impression of the soldiers as die-hard patriots who upon receiving information of an attack took the courage to pursue the country's attackers and subdue them. R24 and R25 capture the bravery of the soldiers who "went all out for action", "beat back" and emerged victorious. By extension, the sinking of the attackers' boat and possibly drowning its occupants is not only considered as a defensive and responsive mechanism but also as a bravery and victorious act, since there was neither material nor human loss on the Cameroonian side. These reports also portray the Cameroon soldiers as superior to their counterparts (the militants) in terms of military powers.

Several lexical expressions are used to express the superiority of the Cameroon security forces through action verbs such as neutralise the rebels; track down on the rebels; give the devil their due; salvage the crumbling internal security machinery in the country and so forth.

\section{Participants' Power Hierarchy}

An analysis of the participants' power hierarchy looks at participants who tend to be construed grammatically as powerful and of those who are construed as less powerful or even powerless. Goatly (2002: 288) made the interesting suggestion that we may construct a hierarchy of participant power relations in any text on the basis of the various roles of the participants in the clauses.

Writers of news in Nigerian newspapers presented an event-oriented reporting style, thereby investing some participants (Nigerians living in Bakassi) with a lot of discursive power in the news, for instance making them to recount their experiences, as seen earlier in the paper. This emotionally engaging style of representation in the news report maximizes the persuasive appeal of the news. When participants with experiential knowledge are engaged in the news to say things, there is the likelihood that their messages will be invested with the ability to have an effect on the emotional response of the readers of the news. News writers in Cameroonian newspapers on the other hand, grammatically construed the Cameroon armed forces as being capable of handling the threat to the country's security. For instance, the newspapers promoted and commended the virtues of the gendarmes and army in combating insurgency in the peninsula. So, in the reports, we can see two ways of portraying power: one, by making some participants to say things that place them at an advantage over other participants and two, by presenting a positive-oriented angle to the actions of some participants. The news media therefore clearly determine what is being said about participants, and how it is said through the structure of experiential meanings in the discourse.

These different angles to the presentation of the news show how the press invest power on participants. Supporting this, van Dijk (1989: 22) says the mass media organisations invest the ability to reproduce and articulate power on participants in news contents through selective, direct editorial influence. This paper has been able to demonstrate that the discursive structure can deliberately invest power on some participants more than others in a discourse in order to influence the persuasive appeal of the news. 
Ebuka Igwebuike and Rotimi Taiwo: Representation of Bakassi Peninsula Conflict in Nigeria 141 and Cameroon Print Media

\section{Conclusion}

This study has attempted a critical discourse analysis of representation of the participants in the Nigeria-Cameroon border clashes in news media reports. Newspapers from each of the countries slant the news to represent the key participants - the Cameroon security forces and Nigerians living in the peninsula as people with social power in the discourse. Nigerian newspapers foreground the torturing experience of Nigerian citizens in the hands of Cameroon security agents, thereby using the news reports to illustrate a broader issue of human right abuse. The episodic framing of the reports emanating from Nigerian newspapers is meant to maximize the persuasive appeal of the news. Cameroon newspapers approach the news by foregrounding the heroic exploits of the security forces of the country in the face of constant attacks from the armed Niger Delta militants, thus commending their performance and projecting the ideology of patriotism. This study has been able to show how news reports on conflicts are shaped by social attitudes and ideological leanings of the news producers.

\section{References}

Chilton, Paul/Schaffner, Christina (2002): "Themes and Principles in the Analysis of Political Discourse". In: Chilton, Paul/Schaffner, Christina (eds.): Politics as Text and Talk: Analytic Approaches to Political Discourse. Amsterdam, Benjamins: 1-41.

Chen, Xiaoxiao (2008): "Reporting on Sino-Japan in The New York Times: A Critical Discourse Analysis". Intercultural Communication Studies 17/1: 139-156.

Chiluwa, Innocent. (2011): "Media representation of Nigeria's Joint Military Task Force in the Niger Delta Crisis". International Journal of Humanities and Social Science 1/9: 197208.

Eggins, Susan (1994): An Introduction to Systemic Functional Linguistics. London: Pinter.

Fairclough, Norman (1995): Media Discourse. London/New York: Edward Arnold.

Fang, Jilian Yu (1994): "'Riots' and Demonstrations in the Chinese Press: A Case Study of Language and Ideology". Discourse and Society 5: 463-481.

Fowler, Roger (1991): Language in the News: Discourse and Ideology in the Press. London/New York: Routledge.

Hall, Stuart (1973): "A World at One with Itself". In: Cohen, Stanley/Young, Jock (eds.): The Manufacture of News: Deviance: Social Problems and the Mass Media. London, Constable: $147-156$.

Goatly, Andrew (2000): Critical Reading and Writing: An Introductory Coursebook. London: Routledge.

Hakam, Jamila (2009). "The 'cartoons controversy': a Critical Discourse Analysis of Englishlanguage Arab newspaper discourse". Discourse and Society 20/1: 33-57.

Halliday, Michael A. K. (1973): Explorations in the Functions of Language. London: Edward Arnold.

Halliday, Michael A. K. (1985): An Introduction to Functional Grammar. London: Edward Arnold.

Hodge, Robert/Gunther, Kress (1993): Language as Ideology, Second Edition. London: Routledge. 
Holquist, Michael (1983): "The Politics of Representation". The Quarterly Newsletter of the Laboratory of Comparative Human Cognition 5/1: 2-9.

Lee, Junghi/Craig, Robert L. (1992): "News as an Ideological Framework: Comparing US Newspapers' Coverage of Labor Strikes in South Korea and Poland". Discourse and Society 3/3: 341-363.

MacRitichie, Victoria/Seedat, Mohamed (2008): "Headlines and Discourses in Newspaper Reports on Traffic Accidents". South African Journal of Psychology 38/2: 337-354.

McLeod, Douglas/Hertog, James K. (1992): "The Manufacture of 'Public Opinion' by Reporters: Informal Cues for Public Perceptions of Protest Groups". Discourse and Society 3/3: 259-275.

Shapiro, Michael (1988.): The Politics of Representation: Writing Practices in Biography, Photography, and Policy Analysis. Madison, WI: University of Wisconsin Press.

Sykes, Mary (1985): "Discrimination in Discourse". In: van Dijk, Teun A. (ed.): Handbook of Discourse Analysis 4. London, Academic Press: 82-102.

Taiwo, Rotimi (2007): "Language, Ideology and Power Relations in Nigerian Newspaper Headlines". Nebula 4 /1: $218-245$.

Taiwo, Rotimi (2011): "Ideology and Power in News Reports on the 2007 Nigerian Presidential Elections in Some Western Online Media". In: Alao, Akin/Taiwo, Rotimi (eds.): Perspectives on African Studies: Essays in Honour of Toyin Falola. München, LINCOM: 295-310.

Tong, Jingrong (2011): Investigative Journalism in China: Journalism, Power, and Society. New York/London: Continuum.

Trew, Tony (1979): "'What the Papers Say': Linguistic Variation and Ideological Difference". In: Fowler, Roger/Hodge, Robert/Kress, Gunther/Trew, Tony (eds.): Language and Control. London, Routledge/Kegan Paul: 117-156.

van Dijk, Teun A. (1989): "Structure of Discourse and Structure of Power". In: Anderson, James A. (ed.): Communication Yearbook 12. Newbury Park, CA, Sage: 18-59.

van Dijk, Teun A. (1998): "Critical Discourse Analysis". In: Tannen, Deborah/Schiffrin,

Demorah/Hamilton, Heidi E. (eds.): The Handbook of Discourse Analysis. Oxford, Blackwell: 352-371.

van Dijk Teun A. (1990): "Social Cognition and Discourse". In: Giles, Howard/Robinson,

Peter W. (eds.): Handbook of Language and Social Psychology. New York, Wiley: 163186.

van Dijk, Teun A. (1991): Racism and the Press. London: Routledge.

van Dijk, Teun A. (2006a): "Discourse and Manipulation". Discourse and Society 17/2: 359383.

van Dijk, Teun A. (2006b): "Ideology and Discourse Analysis". Journal of Political Ideologies 11/2: 115-140.

Wattles, Isidora/Radić-Bojanić, Biljana (2007): "The Analysis of Online Debate: The Systemic Functional Grammar Approach". Facta Universitatis, Linguistics and Literature 5/1: 47-58.

Wenden, Anita L. (2005): "The Politics of Representation: A Critical Discourse Analysis of an Aljazeera Special Report". International Journal of Peace Studies 10/2: 89-112. 
Ebuka Igwebuike and Rotimi Taiwo: Representation of Bakassi Peninsula Conflict in Nigeria 143 and Cameroon Print Media

Yaghoobi, Mahdi (2009): "A Critical Discourse Analysis of Selected Iranian and American Printed Media on the Representations of Hizbullah-Israel War". Journal of Intercultural Communication 21/6. www.immi.se/intercultural/nr21/yaghoobi.htm [25.04.2014].

Youssefi, Kazem/Kanani, Alireza Baghban/Shojaei, Amir (2013): "Ideological or International Move? A Critical Discourse Analysis toward the Representation of Iran Sanctions in Western Printed Media". Journal of Language Teaching and Research 4/6: 1343-1350. 